\title{
Complement Component C1q Enhances Invasion of Human Mononuclear Phagocytes and Fibroblasts by Trypanosoma cruzi Trypomastigotes
}

\author{
Maria T. Rimoldi, ${ }^{*}$ Andrea J. Tenner, ${ }^{\ddagger}$ David A. Bobak, ${ }^{\S}$ and Keith A. Joiner* \\ *Laboratory of Parasitic Diseases and ${ }^{\S}$ Laboratory of Clinical Investigation, National Institute of Allergy and Infectious Diseases, \\ National Institutes of Health, Bethesda, Maryland 20892; and ${ }^{\ddagger}$ American Red Cross, Rockville, Maryland 20855
}

\begin{abstract}
Internalization and infectivity of Trypanosoma cruzi trypomastigotes by macrophages is enhanced by prior treatment of parasites with normal human serum. Heating serum or removing Clq from serum abrogates the enhancement, but augmentation of attachment and infectivity is restored by addition of purified $\mathrm{Clq}$ to either serum source. Although both noninfective epimastigotes (Epi) and vertebrate-stage tissue culture trypomastigotes (TCT) bind $\mathrm{Clq}$ in saturable fashion at $4^{\circ} \mathrm{C}$, internalization by monocytes and macrophages of TCT but not Epi-bearing C1q is enhanced in comparison to untreated parasites. Adherence of human monocytes and macrophages to surfaces coated with $\mathrm{Clq}$ also induces a marked enhancement of the internalization of native TCT.

C1q enhances attachment of both Epi and TCT to human foreskin fibroblasts, but only when $\mathrm{Clq}$ is on the parasite and not when the fibroblasts are plated on C1q-coated surfaces. Only TCT coated with C1q show enhanced invasion into fibroblasts.
\end{abstract}

Although trypomastigotes produce an inhibitor of the complement cascade which limits $\mathbf{C 3}$ deposition during incubation in normal human serum, C1q binds to the parasite and enhances entry of trypomastigotes into target cells.

\section{Introduction}

Infection of monocytes and macrophages by Leishmania spp. (1-3), Legionella pneumophila (4), Mycobacterium tuberculosis (5), and Histoplasma capsulatum (6) is blocked with monoclonal antibodies to receptors for the third component of complement, CR1 and CR3. Furthermore, productive infection of macrophages by these organisms is markedly enhanced by incubation of the organisms in serum before allowing cell attachment and entry to proceed. These findings, which are most thoroughly developed with Leishmania major $(2,3)$ and Leishmania donovani (1), have led to the notion that C3 fragments deposited during incubation in serum or derived from local production by macrophages $(7,8)$ are necessary for cell attachment and entry. An alternative mechanism has now been proposed for serum-independent uptake of Leishmania mexicana via CR3 (9). Nonetheless, the central involvement

Address reprint requests to Dr. Joiner, Division of Infectious Disease, P.O. Box 3333, Yale University School of Medicine, New Haven, CT 06510.

Received for publication 10 January 1989 and in revised form 6 June 1989.

The Journal of Clinical Investigation, Inc.

Volume 84, December 1989, 1982-1989 of CR1 and CR3 has only been postulated for organisms with an obligatory residence in professional phagocytic cells.

Trypanosoma cruzi, the causative agent of Chagas disease, is an intracellular parasite closely related to Leishmania spp., but with a broad host cell range (reviewed in Zingales and Colli [10]). The type of disease caused by $T$. cruzi, in which cells of connective tissue origin such as fibroblasts and muscle cells are predominantly infected, differs markedly from that of clinical Leishmania infection involving macrophages of either the cutaneous, subcutaneous or visceral organs. Although vectorstage epimastigotes (Epi) ${ }^{1}$ and vertebrate-stage trypomastigotes of $T$. cruzi are internalized within mononuclear phagocytes, only the biologically relevant trypomastigote stage infects other types of cells (10).

The ligands and receptors involved in cell uptake of $T$. cruzi trypomastigotes following serum incubation are not defined. Nogueira and Cohn (11) suggested that C3 receptors were not involved in the uptake process, since trypsinization of macrophages did not affect trypomastigote attachment but did diminish binding of complement-coated erythrocytes. In more recent studies by our laboratory (Rimoldi, M. T., and K. A. Joiner, unpublished observations) and others (12), treatment of trypomastigotes with serum augmented uptake into human and mouse macrophases, but the augmentation was not blocked using monoclonal antibodies directed against CRI and CR3. In contrast, uptake of non-infective epimastigotes after autologous serum incubation is significantly inhibited by anti-CR3 antibodies. These findings are reflective of the difference in deposition of $\mathrm{C} 3$ on the parasite surface during incubation in serum. Epi bear large numbers of $\mathrm{C} 3$ molecules after serum incubation (13-15), whereas deposition of $\mathrm{C} 3$ on the trypomastigote surface is limited by a $\mathrm{C} 3$ convertase inhibitor produced by this stage (16-18).

We therefore sought another explanation for the serummediated enhancement of internalization of trypomastigotes into phagocytic cells. We report here that complement component $\mathrm{Clq}$ enhances invasion of human mononuclear phagocytes and fibroblasts by trypomastigotes of $T$. cruzi.

\section{Methods}

Buffers and reagents. The following buffers were used: Hanks' buffered salt solution (HBSS) containing $10 \mathrm{mg} / \mathrm{ml}$ bovine serum albumin (BSA) (Boehringer-Mannheim) (HBSS-BSA); HBSS containing 20 $\mathrm{mg} / \mathrm{ml}$ sucrose (HBSS-S); RPMI-1640 (Gibco Laboratories, Grand Island, NY) containing $2 \mathrm{mM}$ glutamine and $10 \mathrm{mg} / \mathrm{ml} \mathrm{BSA}$; HLl

1. Abbreviations used in this paper: BESM, bovine embryo skin muscle; Epi, epimastigote(s); HINHS, normal human serum heated to inactivate complement; HLB, hypotonic lysing buffer; NHS, normal human serum; NPGB, nitrophenyl guanidino benzoate; TCT, tissue culture trypomastigote(s). 
serum-free defined media (Ventrex Lab, Portland, ME); phosphatebuffered saline (PBS); PBS containing 1\% glutaraldehyde (PBS-glutaraldehyde); hypotonic lysing buffer (HLB) containing $10 \mathrm{mM}$ Tris and 2 mM EDTA, pH 8.

Nitrophenyl guanidino benzoate (NPGB) was obtained from Sigma Chemical Co. (St. Louis, MO). Purified human plasma fibronectin was generously provided by Dr. Alex Kurosky, Galveston, TX. When analyzed by SDS-PAGE under reducing conditioning, $>95 \%$ of the fibronectin migrated as a band of 200-220 kD. The peptide arginine-glycine-aspartic acid-serine (RGDS) was purchased (Peninsula Laboratories, Inc., Belmont, CA). The peptide gave a single peak when analyzed by high-performance liquid chromatography (LKB Instruments, Inc., Gaithersburg, MD) using a reverse-phase C18 column (Altex, Berkeley, CA).

Parasites. The Y strain and the Miranda 88 (M88) clone of $T$. cruzi were obtained from Dr. J. A. Dvorak (Bethesda, MD). The Epi were maintained by serial passage in liver-infusion tryptose broth, (Oxoid, Basingstoke, Hanks, UK) containing $10 \%$ (vol/vol) fetal calf serum, $0.02 \mathrm{mg} / \mathrm{ml}$ hemin; $100 \mu / \mathrm{ml}$ penicillin, and $100 \mu \mathrm{g} / \mathrm{ml}$ streptomycin. Epi in log-phase growth $(3 \mathrm{~d})$ were harvested at a parasite density of 5 $\times 10^{6} / \mathrm{ml}$. M88 clone TCT were maintained by serial passages in bovine embryo skin muscle cell (BESM) cultures in RPMI-1640 containing $2 \%$ fetal calf serum, using culture conditions previously described (17). Y strain tissue culture trypomastigotes (TCT) were grown in $\operatorname{LLCMK}_{2}$ cells as described $(17,18)$. The final suspensions from BESM or $\mathrm{LLCMK}_{2}$ cultures consisted predominantly of motile trypomastigotes; amastigotes and intermediate developmental forms were always present but never exceeded $5 \%$ of the total suspension.

Serum. Normal human sera (NHS) were collected and frozen in aliquots at $-70^{\circ} \mathrm{C}$. Some samples of serum were heated at $56^{\circ} \mathrm{C}$ for 30 min to inactivate complement (HINHS). Human serum was also depleted of Clq and factor D (Clq D serum) using a BioRex 70 column (Bio-Rad Laboratories, Richmond, CA) at pH 7.3 as described (19). The absence of $\mathrm{Clq}$ was verified by hemolytic titer as described by Kolb et al. (20). This method can detect $<0.4 \mathrm{ng} \mathrm{Clq}$. Human $\mathrm{AB}$ serum was collected from a normal volunteer and heated at $56^{\circ} \mathrm{C}$ for $30 \mathrm{~min}$. Neither sera contained detectable antibodies for $T$. cruzi as measured by indirect immunofluorescence at a dilution of $1: 10$.

Purification and radiolabeling of $C 1$ subcomponents. $\mathrm{Clq}$ was isolated from human serum or plasma as described previously (19) and radiolabeled with $\mathrm{Na}{ }^{125} \mathrm{I}$ (Amersham International, Arlington Heights, IL) to an average specific radioactivity of $0.5 \mu \mathrm{C} / \mu \mathrm{g}$. Purified Clq gave one band on SDS-PAGE. When tested by double immunodiffusion, purified $\mathrm{Clq}$ gave no line when tested against antiserum to high density lipoprotein, to "Cruzin," the serum inhibitor of $T$. cruzi neuraminidase (21) (antiserum kindly provided by M. E. A. Pereira, Tufts University, Boston, MA), or to fibronectin. C1r, C1s, and C1 inhibitor were isolated as previously described (22-24). C1s was radioiodinated in the presence of $5 \mathrm{mM} \mathrm{CaCl}_{2}$ (25) using Enzymobeads (Bio-Rad Laboratories) to a specific radioactivity of $0.5 \mu \mathrm{C} / \mu \mathrm{g}$. Native $\mathrm{Cl}$ was reconstituted in the presence of $5 \mathrm{mM} \mathrm{CaCl}_{2}$ by incubating equimolar amounts of purified $\mathrm{Clq}, \mathrm{Clr}_{2}$, and trace-labeled ${ }^{125} \mathrm{I}^{-\mathrm{Cl}_{2}} \mathrm{~s}_{2}$ for $20 \mathrm{~min}$ at $0^{\circ} \mathrm{C}(26)$.

Internalization of TCT by macrophages: effect of incubation in serum. Long-term culture monocyte-derived macrophages were prepared (Sechler, J. M., M. K. Warren, and J. I. Gallin, manuscript in preparation). Mononuclear cells were obtained from peripheral blood by separation on Histopaque cushions and were maintained in culture for at least 1 mo by replating those initially adherent cells which spontaneously lifted off of culture plates into new flasks. Cells were $>99 \%$ nonspecific esterase positive and had typical macrophage morphology. Cells expressed Fc, CR1, and CR3 receptors, as determined by sheep cell rosetting, and expressed FMLP receptors, as determined by affinity labeling. Macrophages were avidly phagocytic for opsonized Candida albicans and responded to $\gamma$-interferon with enhanced production of superoxide on stimulation with phorbol myristate acetate (PMA). Macrophages prepared as described were plated in $1 / 2-$ in. petri dishes in RPMI- 1640 with $5 \%$ heat-inactivated human AB serum and allowed to adhere in the petri dishes for at least $24 \mathrm{~h}$ at $37^{\circ} \mathrm{C}$ in $5 \% \mathrm{CO}_{2}$. TCT (Y strain) $\left(10^{8} / \mathrm{ml}\right)$ were preincubated for $10 \mathrm{~min}$ at $37^{\circ} \mathrm{C}$ in medium (RPMI-1640 with 5\% heated human AB serum) or with one of the following sources of serum: $20 \%$ NHS, $20 \%$ HINHS, $20 \%$ ClqD, $20 \%$ HINHS with addition of $200 \mu \mathrm{g} / \mathrm{ml} \mathrm{Clq}$, or $20 \% \mathrm{ClqD}$ with addition of $200 \mu \mathrm{g} / \mathrm{ml} \mathrm{Clq}$. The TCT were then washed twice in RPMI-1640 containing $5 \%$ human $\mathrm{AB}$ serum, added to the petri dishes at a parasite/cell ratio of $10: 1$, and incubated for $2 \mathrm{~h}$ at $37^{\circ} \mathrm{C}$ in $5 \% \mathrm{CO}_{2}$. Noninternalized parasites were removed by hypotonic lysis with HLB. In all experiments reported in this manuscript using monocytes and macrophages, only internalized parasites were enumerated. Although this procedure will not identify ligands which enhance attachment only, it unambiguously identifies ligands which facilitate internalization. After fixation and staining with Leukostat (Fisher Scientific, Springfield, NJ), internalization was determined by light microscopy.

In experiments to test the effect of Clq on TCT infectivity, parasites incubated in serum and washed as described above were added to long-term culture monocyte-derived macrophages. Incubation was carried out for $2 \mathrm{~h}$ at $37^{\circ} \mathrm{C}$ in $5 \% \mathrm{CO}_{2}$; non-cell-associated parasites were washed away, and incubation was continued for an additional 48 h. The number of internalized parasites, consisting almost exclusively of amastigotes, was assessed as described above.

${ }^{125} \mathrm{I}$-Clq binding to T. cruzi. Binding of monomeric ${ }^{125} \mathrm{I}-\mathrm{Clq}$ to Epi and TCT (M88 clone) was performed by incubating triplicate tubes containing $10^{7}$ parasites in HBSS-BSA with increasing amounts of a mixture of ${ }^{125} \mathrm{I}$-labeled and unlabeled $\mathrm{Clq}$ in a total volume of $100 \mu \mathrm{l}$. After incubation on ice for $20 \mathrm{~min}$, the reaction mixture was layered over a $150-\mu \mathrm{l}$ cushion of HBSS-S and centrifuged at $10,000 \mathrm{~g}$ for $30 \mathrm{~s}$ at $4^{\circ} \mathrm{C}$ in a microcentrifuge (Microfuge, Beckman Instruments, Inc., Fullerton, CA). The parasite pellet and the tube with the remaining supernatant were counted separately in a $\gamma$ scintillation counter (Packard MultiPrias 4, Packard Instrument Co., Inc., Downers Grove, IL). In certain samples, unlabeled $\mathrm{Clq}$ (up to 100 -fold molar excess over ${ }^{125} \mathrm{I}-\mathrm{Clq}$ ) was also added to determine nonspecific binding of ${ }^{125}$ I-Clq. Nonspecific uptake was usually $1 \%$ or less of total input and $15 \%$ or less of total bound radioactivity. Experimental values were corrected by subtraction of nonspecific uptake.

Cleavage of Cls by T. cruzi. An aliquot of $20 \mu \mathrm{l}$ of reconstituted $\mathrm{Cl}$ containing ${ }^{125} \mathrm{I}-\mathrm{C} 1 \mathrm{~s}$ in HBSS-BSA was added to a pellet containing $10^{7}$ or $2 \times 10^{7}$ parasites (M88 clone). The samples containing $\mathrm{Cl}$ at or near serum concentration $\left(1.8 \times 10^{-7} \mathrm{M}\right)$ were incubated at $30^{\circ} \mathrm{C}$ for 10 min. In some experiments, a physiologic concentration of $\mathrm{C} 1$ inhibitor $(\mathrm{C} 1 \mathrm{Inh})\left(1.3 \times 10^{-6} \mathrm{M}\right)$ or $25 \mu \mathrm{M}$ NPGB was added. Reactions were stopped by the addition of equal volumes of SDS-PAGE sample buffer containing $15 \mathrm{mM}$ dithiothreitol and incubated for $45 \mathrm{~min}$ at $37^{\circ} \mathrm{C} . \mathrm{Cl}$ activation was assayed by SDS-PAGE under reducing conditions as previously described (26). In some experiments, $10^{7}$ or $2 \times 10^{7}$ parasites were incubated in a volume of HBSS-BSA identical to that of the ${ }^{125} \mathrm{I}-\mathrm{Cl}$ for $10 \mathrm{~min}$ at $30^{\circ} \mathrm{C}$. Parasites were pelleted, and the supernatant was assayed for its ability to activate $\mathrm{Cl}$ in the presence and absence of $\mathrm{C} 1 \mathrm{Inh}$. Control tubes contained aggregated $\mathrm{IgG}(1 \mathrm{mg} / \mathrm{ml})$ in the presence or absence of $\mathrm{Cl}$ inhibitor.

Degradation of Clq by T. cruzi. A volume of $95 \mu \mathrm{l}$ containing 2.5 $\times 10^{8}$ parasites $/ \mathrm{ml}$ (M88 clone) was mixed with $5 \mu \mathrm{l}(20 \mu \mathrm{g})$ of ${ }^{125} \mathrm{I}-\mathrm{Clq}$ at $0^{\circ} \mathrm{C}$ and incubated for 10 and $30 \mathrm{~min}$ at $37^{\circ} \mathrm{C}$. The samples were centrifuged at $10,000 \mathrm{~g}$ for $30 \mathrm{~s}$ at $4^{\circ} \mathrm{C}$ in a microcentrifuge (Microfuge) and the pellet and the supernatant were separated. The pellet was divided into equal aliquots and treated with sample buffer with or without 2-mercaptoethanol. Samples were electrophoresed in $10 \%$ SDS-PAGE in the presence of urea, and the percentage of degradation of bound Clq was quantitated by densitometric scanning (Ultrascan XL, LKB Produkter, Bromma, Sweden) of the autoradiogram.

Internalization of $T$. cruzi-bearing Clq by monocytes and macrophages. Human peripheral blood monocytes were isolated by counterflow elutriation using a modification of the technique of Lionetti et al. (27) as described (28). Macrophages, as defined here for the serum-free experiments, were elutriated monocytes that had been cultured in Teflon jars (Savillex Corp., Minnetonka, MN) at $1 \times 10^{6} \mathrm{cells} / \mathrm{ml}$ in 
HL1 containing $2 \mathrm{mM}$ L-glutamine and $10 \mu \mathrm{g} / \mathrm{ml}$ of gentamicin in $5 \%$ $\mathrm{CO}_{2}$ at $37^{\circ} \mathrm{C}$. On day 7 of culture, macrophages were harvested from the Teflon jars by vigorous pipetting and washed twice in PBS before use. Effector cells (monocytes or macrophages) were suspended in RPMI-1640 medium containing $2 \mathrm{mM} \mathrm{L}$-glutamine, $5 \mathrm{mM} \mathrm{MgCl}$, and $10 \mu \mathrm{g} / \mathrm{ml}$ gentamicin at $2.5 \times 10^{5} / \mathrm{ml}$, and $250 \mu \mathrm{l}\left(6.25 \times 10^{4}\right.$ cells $)$ was added to each well of a Lab-Tek chamber previously coated with BSA $(40 \mu \mathrm{g} / \mathrm{ml})$. The cells were allowed to adhere for $1 \mathrm{~h}$ at $37^{\circ} \mathrm{C}$ in $5 \% \mathrm{CO}_{2}$. TCT or Epi (M88 clone) at $1 \times 10^{8} / \mathrm{ml}$ were pretreated for $15 \mathrm{~min}$ at $0^{\circ} \mathrm{C}$ with $\mathrm{Clq}(200 \mu \mathrm{g} / \mathrm{ml})$, washed twice at $4^{\circ} \mathrm{C}$, and added in a parasite/mononuclear cell ratio of 10:1. Chambers were centrifuged at room temperature for $3 \mathrm{~min}$ at $100 \mathrm{~g}$ and were incubated for $30 \mathrm{~min}$ at $37^{\circ} \mathrm{C}$ in $5 \% \mathrm{CO}_{2}$. Noninternalized parasites were removed by hypotonic lysis with HLB. After fixation with PBS-glutaraldehyde and staining with Giemsa, internalization was determined by light microscopy.

Internalization of T. cruzi by monocytes or macrophages adhered in the presence or absence of Clq. Eight-well Lab-Tek chambers (Miles Laboratories, Naperville, IL) were incubated with $\mathrm{Clq}(30 \mu \mathrm{g} / \mathrm{ml})$ or BSA $(40 \mu \mathrm{g} / \mathrm{ml})$ in $0.1 \mathrm{M}$ carbonate buffer, $\mathrm{pH} 9.5$, for $2 \mathrm{~h}$ at room temperature. Chambers were washed twice with PBS immediately before use.

Monocytes and macrophages, prepared as described above, were added and allowed to adhere for $1 \mathrm{~h}$ at $37^{\circ} \mathrm{C}$ in $5 \% \mathrm{CO}_{2}$. The experiments were performed by adding parasites (M88 clone) at a parasite/ cell ratio of 10:1.

Attachment of $T$. cruzi-bearing Clq to human foreskin fibroblasts. Human foreskin fibroblasts were obtained from the American Type Culture Collection, Rockville, MD (ATCC No. CRL1635) and maintained at low passage number in Eagle's minimal essential medium containing $10 \%$ fetal calf serum, $2 \mathrm{mM} \mathrm{L-glutamine,} 100 \mathrm{U} / \mathrm{ml}$ penicillin, and $100 \mu \mathrm{g} / \mathrm{ml}$ streptomycin. For use in experiments, cells were released with trypsin/EDTA and plated overnight on glass coverslips (12 mm, No. 1, Fisher Scientific Co., Pittsburgh, PA) at $2 \times 10^{4}$ cells per coverslip. TCT or Epi in PBS at $2 \times 10^{7} / \mathrm{ml}$ were pretreated for 15 min at $0^{\circ} \mathrm{C}$ with buffer or (a) Clq at $100 \mu \mathrm{g} / \mathrm{ml},(b) \mathrm{Clq}(100 \mu \mathrm{g} / \mathrm{ml})$ and RGDS $(50 \mu \mathrm{g} / \mathrm{ml}),(c)$ human plasma fibronectin at $100 \mu \mathrm{g} / \mathrm{ml}$, or (d) human plasma fibronectin $(100 \mu \mathrm{g} / \mathrm{ml})$ and RGDS $(50 \mu \mathrm{g} / \mathrm{ml})$. Parasites were washed twice at $4^{\circ} \mathrm{C}$ in PBS. Aliquots of the sample from $a$ were suspended in PBS and incubated for an additional $20 \mathrm{~min}$ in buffer alone or buffer containing $200 \mu \mathrm{g} / \mathrm{ml}$ of the $\mathrm{F}\left(\mathrm{ab}^{\prime}\right)_{2}$ fragment of anti-Clq prepared as described earlier (29). All parasite preparations were added to fibroblasts on coverslips in 24-well plates at a 20:1 parasite/cell ratio. Plates were centrifuged at room temperature for 3 min at $100 \mathrm{~g}$ and incubated for $60 \mathrm{~min}$ at $37^{\circ} \mathrm{C}$ in $5 \% \mathrm{CO}_{2}$. Total cell-associated parasites were determined by washing coverslips six times in PBS followed by fixation with PBS glutaraldehyde and staining with Leukostat. Internalized parasites were assessed by first removing noninternalized parasites with HLB.

Attachment of T. cruzi to human foreskin fibroblasts plated on Clq. Human foreskin fibroblasts were plated on coverslips precoated with either buffer, Clq alone, or Clq followed by anti-Clq. Coating with $\mathrm{Clq}$ was exactly as described for macrophages and monocytes. Subsequent incubation with $\mathrm{F}\left(\mathrm{ab}^{\prime}\right)_{2}$ anti-Clq $(200 \mu \mathrm{g} / \mathrm{ml})$ was carried out for $30 \mathrm{~min}$ at $4^{\circ} \mathrm{C}$ after first washing away nonbound $\mathrm{Clq}$; then unbound antibody was removed by washing. Parasites were added at a 20:1 parasite/cell ratio, and further incubations carried out as described above.

\section{Results}

Uptake of TCT by macrophages: effect of incubation in serum. Initial experiments showed that uptake of TCT by macrophages was augmented by incubation in normal human serum (Fig. 1). Heating serum or depleting serum of Clq and factor D abrogated the serum mediated enhancement of cell entry (Fig. 1). When heated serum or $\mathrm{Clq}$ and $\mathrm{fD}$ deficient serum were

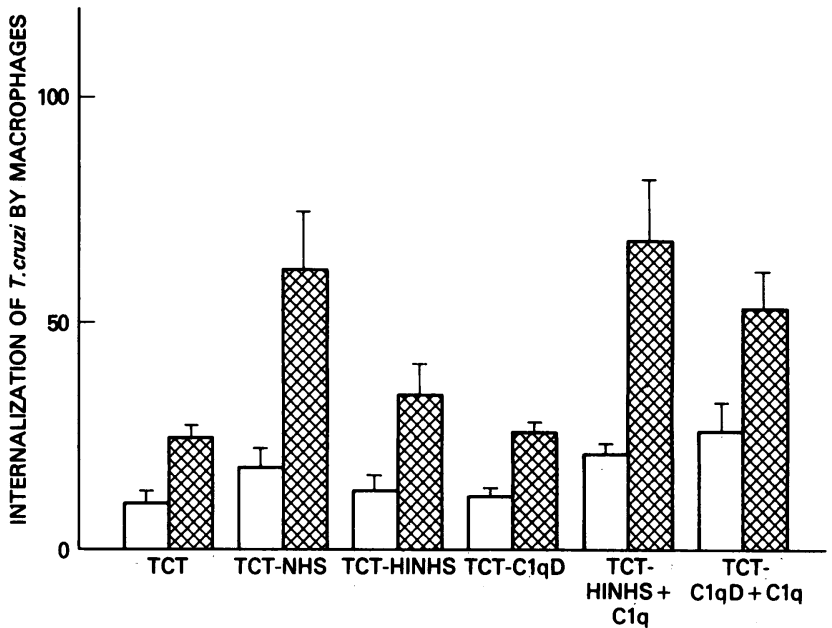

Figure 1. Uptake of TCT by macrophages: effect of incubation in serum. TCT ( $Y$ strain) were incubated for $10 \mathrm{~min}$ at $37^{\circ} \mathrm{C}$ in the serum sources indicated, then mixed with long-term culture monocyte-derived macrophages at a parasite cell ratio of 10:1. After incubation for $2 \mathrm{~h}$ at $37^{\circ} \mathrm{C}$, internalized parasites were determined as described in Methods. The number of parasites inside 100 cells is defined as the internalization index (cross-hatched bars); the percentage of cells with at least one parasite is referred to as the "percent of internalization" (open bars). At least 200 cells were assessed per dish. Data shown are the mean \pm SD from three experiments, each done in duplicate dishes. Results with TCT-HINHS and TCT-C1qD were not different from TCT alone ( $P>0.05$ by $t$ test).

reconstituted with purified $\mathrm{Clq}$, the serum-dependent enhancement was restored. These results suggest that the $\mathrm{Clq}$ derived from normal human serum is necessary for the observed enhancement of internalization of serum-incubated TCT by macrophages.

Infectivity of TCT for macrophages: effect of incubation in serum. Enhanced entry of parasites into cells is not synonymous with enhanced survival and replication within cells. We therefore investigated whether $\mathrm{Clq}$ in serum also augmented parasite infectivity in macrophages. Compared with parasites incubated in NHS, treatment of TCT with ClqD and factor D-deficient serum resulted in fewer parasites per infected macrophage after $48 \mathrm{~h}$ of culture (Fig. 2). Adding $\mathrm{Clq}$ but not factor $\mathrm{D}$ restored the level of infection to that observed with NHS. A portion of the infected cells, greater in the presence of $\mathrm{Clq}$, was released into the supernatant during $48 \mathrm{~h}$ of culture. It was not possible, therefore, to accurately compare the total number of cell associated parasites at 2 and $50 \mathrm{~h}$ under different serum incubation conditions to determine whether $\mathrm{Clq}$ augmented growth of internalized TCT.

Binding of Clq to T. cruzi. We next sought to determine if purified Clq bound to $T$. cruzi. Representative data are shown in Fig. 3 and demonstrate that, in a serum-free system, the binding of $\mathrm{Clq}$ to Epi and TCT at $4^{\circ} \mathrm{C}$ is concentration-dependent and saturable. The calculated number of $\mathrm{Clq}$ binding sites at saturation was $5.2 \times 10^{3}$ sites per Epi and $5.8 \times 10^{3}$ sites per TCT, although Epi consistently showed higher apparent affinity for Clq (data not shown).

Activation of $C l$ by $T$. cruzi. We examined the ability of Epi and TCT to activate human $\mathrm{Cl}$ which had been reconstituted from purified components (C1q, $\left.\mathrm{Cl}_{2},{ }^{125} \mathrm{I}-\mathrm{C} 1 \mathrm{~s}_{2}\right)$. Fig. 4 shows that while $\mathrm{C} 1$ was activated by aggregated $\mathrm{IgG}$, as detected by the shift of radioactivity from the $87-\mathrm{kD}$ proenzyme 


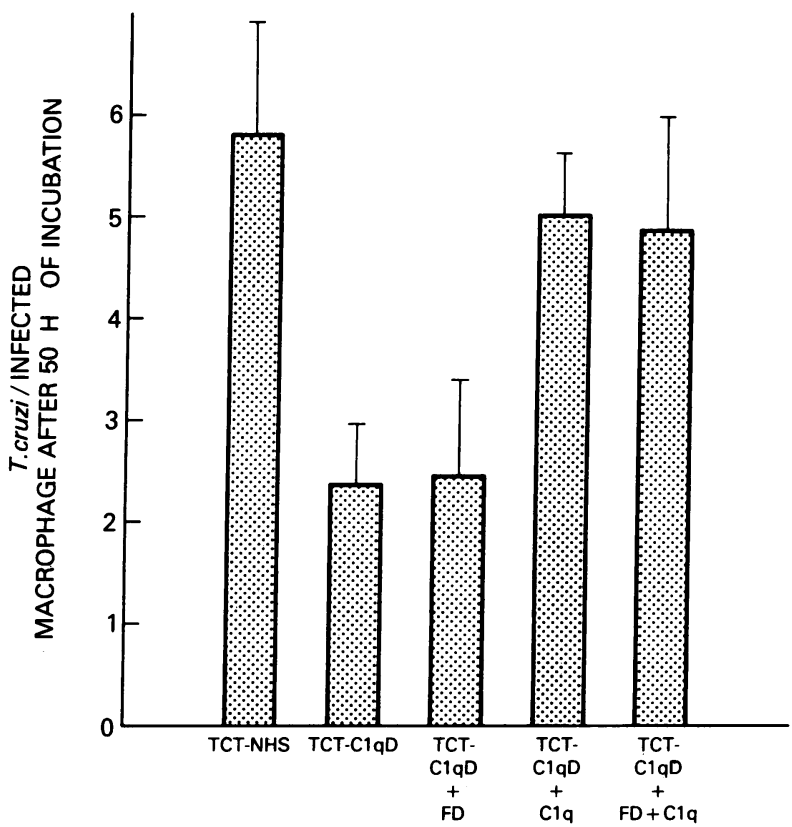

Figure 2. Infectivity of $T$. cruzi in macrophages: effect of incubation in serum. TCT ( $Y$ strain) were incubated with serum and added to macrophages as described in the legend to Fig. 1. Noninternalized parasites were removed by washing, and incubation was continued for $48 \mathrm{~h}$. The number of parasites per infected cell at $50 \mathrm{~h}$ was determined as described in Methods. Data shown are the mean \pm SD from two experiments, each done in duplicate dishes.

C1s polypeptide chain to the $59-\mathrm{kD}$ chain resulting from cleavage of $\mathrm{Cls}$, no $\mathrm{Cl}$ activation was found during incubation with either Epi or TCT. Instead, a decrease in intensity of the 87-kD band was seen, with the appearance of multiple lower molecular weight degradation fragments. This degradation of $\mathrm{Cls}$, which was more extensive with TCT $(65 \%$ cleavage by densitometric scanning) than with Epi (43\% cleavage), occurred in the presence and absence of $\mathrm{Cl}$ inhibitor and in the presence of the serine esterase inhibitor NPGB (data not shown). No activation or proteolysis of $\mathrm{C} 1$ was detected when the supernatant of the parasites was used in the $\mathrm{Cl}$ activation assay (data not shown).

Cleavage of Clq by $T$. cruzi. Since $C 1$ s within intact $C 1$ was degraded by Epi and TCT, we questioned whether isolated $\mathrm{Clq}$ was also cleaved by the parasites. ${ }^{125} \mathrm{I}-\mathrm{Clq}$ was incubated with TCT and Epi for 10 and $30 \mathrm{~min}$ at $37^{\circ} \mathrm{C}$. After $10 \mathrm{~min}$ of incubation, $36 \%$ of $\mathrm{Clq}$ bound to Epi was cleaved, whereas $<10 \%$ of Clq on TCT was degraded. By 30 min of incubation, $91 \%$ of $\mathrm{Clq}$ on Epi was proteolytically cleaved, in comparison with $39 \%$ on TCT. No cleavage was observed when Clq was

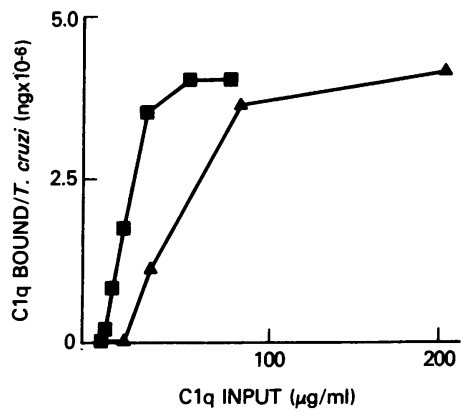

Figure 3. Binding of ${ }^{125} \mathrm{I}$ Clq to T. cruzi. ${ }^{125} \mathrm{I}-\mathrm{Clq}$ binding to TCT ( $\triangle$ ) and Epi $(\varpi)$ is plotted as a function of $\mathrm{Clq}$ concentration. Results shown are the mean of triplicate samples in a representative experiment.

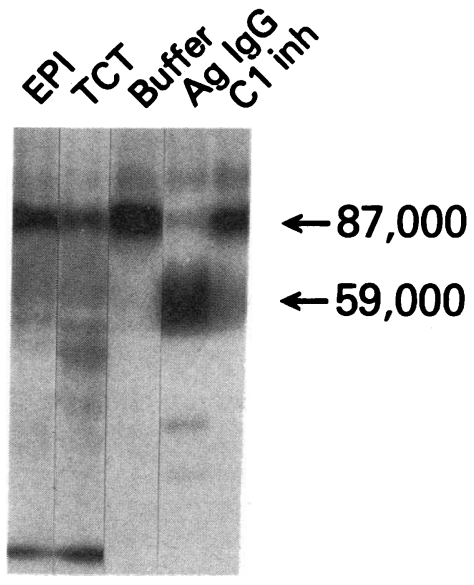

Figure 4. Activation of $\mathrm{Cl}$ by $T$. cruzi. SDS-PAGE analysis of ${ }^{125} \mathrm{I}-\mathrm{Cl}$ s within reconstituted $\mathrm{Cl}$ after incubation for $10 \mathrm{~min}$ at $30^{\circ} \mathrm{C}$ with Epi, TCT, or buffer. Control tubes were incubated with aggregated IgG in the presence or absence of $\mathrm{Cl}$ inhibitor.

incubated with buffer or with the supernatant of parasites (not shown).

Internalization of T. cruzi by monocytes and macrophages: effect of incubating parasites with C1q. The role of purified $\mathrm{Clq}$ on parasite internalization by monocytes and macrophages was tested. Preliminary experiments indicated that there was a dose-related increase in internalization of trypomastigotes by monocytes when parasites were pretreated with concentrations of $\mathrm{Clq}$ ranging from 25 to $200 \mu \mathrm{g} / \mathrm{ml}$ (not shown). Since $\mathrm{Clq}$ at $200 \mu \mathrm{g} / \mathrm{ml}$ gave saturable binding on TCT (Fig. 3), this concentration was used to provide maximum reproducibility between experiments. The percentage of internalization and the internalization index for TCT pretreated with $200 \mu \mathrm{g} / \mathrm{ml}$ of $\mathrm{Clq}$ for $15 \mathrm{~min}$ at $0^{\circ} \mathrm{C}$ were enhanced 2.2- and 2.7-fold, respectively, over native TCT entry into monocytes (Fig. $5 \mathrm{~A}$ ). The extent of enhancement was similar when macrophages were used as the target cell (Fig. 5 $B$ ). No differences were found when Epi bearing Clq were compared with Epi alone for entry into monocytes (Fig. $5 A$ ) or macrophages (Fig. 5 B).

Internalization of $T$. cruzi by monocytes and macrophages: effect of plating cells on Clq. We tested whether plating monocytes or macrophages on Clq-coated surfaces enhanced parasite internalization, analogous to the effects of Clq on enhancing phagocytosis of other particles (28). A marked enhancement of internalization of TCT but not Epi resulted when monocytes were adhered to Clq-coated surfaces (Fig. 6 $A)$. The percentage of internalization and the internalization index were increased 2.4- and 3.7-fold, respectively, when TCT entry into monocytes adhered to Clq-coated surfaces was compared to entry into cells adhered onto BSA-coated surfaces (Fig. $6 \mathrm{~A}$ ). In contrast, when Epi were used as target cells, no significant increase in either percentage of internalization or internalization index was found with monocytes adhered to a Clq-coated surface (Fig. $6 \mathrm{~A}$ ). Results for TCT were similar when macrophages were adhered to Clq-coated wells (Fig. $6 \mathrm{~B}$ ). Internalization of Epi into macrophages plated on Clq was not enhanced in comparison to cells adhered to a BSA-coated surface.

Attachment and internalization of $T$. cruzi bearing Clq by human foreskin fibroblasts. The capacity of $\mathrm{Clq}$ to augment parasite attachment and internalization by fibroblasts was tested. We examined attachment as well as internalization with fibroblasts, since Epi are not internalized by these cells $(30,31)$. Attachment of both Epi and TCT was augmented by 

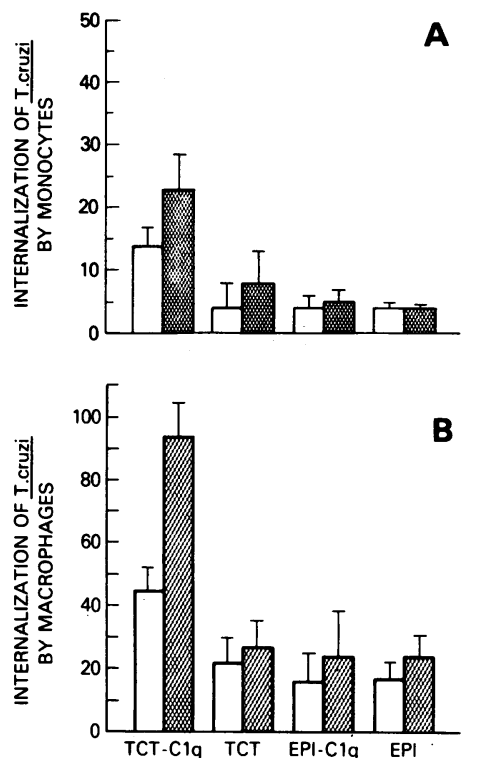

B

Each experiment with duplicate wells was performed three times. The results were compared by using the Student's $t$ test. When TCT-C1q were used to infect the monocytes, the mean values differ significantly from the mean value of the control at the $P<0.01$. No differences were found when Epi treated with $\mathrm{Clq}$ were compared with native Epi for internalization by monocytes. When TCT pretreated with $\mathrm{Clq}$ were used to infect macrophages, internalization was enhanced significantly in comparison to non-pretreated TCT. Internalization of Epi by macrophages was not significantly enhanced by pretreatment with $\mathrm{Clq}(0.1<P<0.2)$. Results were similar for all conditions when parasite/cell ratios of 5:1 and 20:1 were compared with the data presented here (not shown).

Clq. Both the percentage of cells associated with parasites (Fig. $7 a$ ) and the total number of parasites/100 cells (Fig. $7 b$ ) were enhanced. Results were not altered by inclusion of the peptide RGDS with the parasites during incubation with Clq. Incubation of Clq-coated parasites with $\mathrm{F}\left(\mathrm{ab}^{\prime}\right)_{2}$ anti-Clq significantly decreased the percentage of cells associated with parasites and the total number of parasites per 100 cells. Fibronectin also enhanced attachment of both Epi and TCT to fibroblasts, an effect blocked by RGDS.

In contrast to results with attachment, internalization of TCT but not Epi was augmented by $\mathrm{Clq}$ and fibronectin (Fig. $7 \mathrm{c}$ ). These findings are analogous to the results with monocytes and macrophages (Fig. 5).

Attachment and internalization of $T$. cruzi by human foreskin fibroblasts plated on Clq. Attachment of Epi and TCT to fibroblasts was not altered when cells were plated on Clqcoated surfaces or Clq and anti-Clq-coated surfaces (Table I). Furthermore, there was no significant effect of either ligand on parasite internalization when compared to cells plated on buffer alone.

\section{Discussion}

We have shown that internalization of trypomastigotes of $T$. cruzi by both phagocytic cells and fibroblasts is enhanced by the complement subcomponent Clq. The molecular mechanism by which Clq enhances the internalization of $T$. cruzi or of other particles is unknown. Conceptually, in any interaction between ligand and a cell surface receptor, the ligand can directly mediate internalization via interaction with a cell sur-
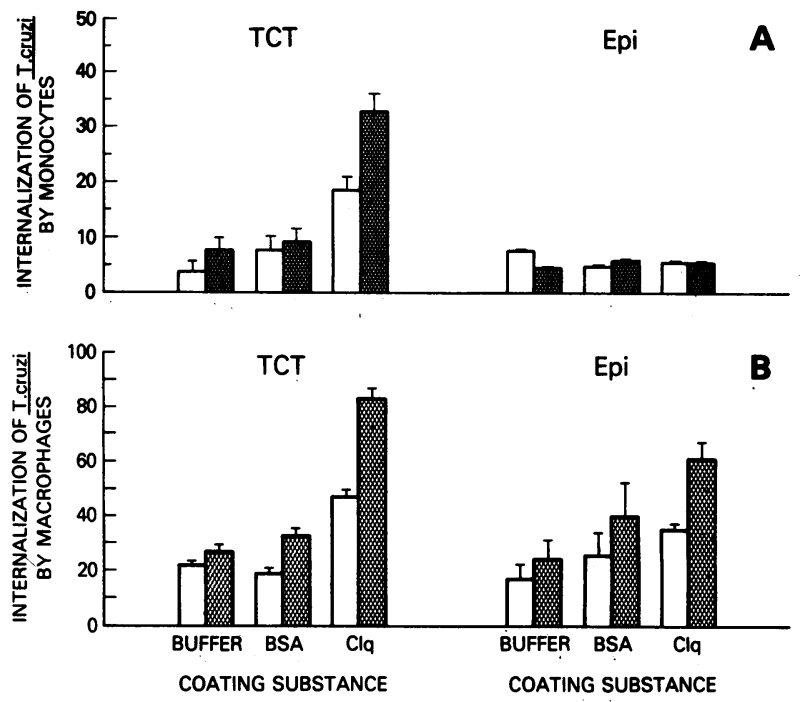

Figure 6. Internalization of $T$. cruzi by monocytes and macrophages: effect of plating cells on Clq. TCT were added at a 10:1 parasite/cell ratio to $(A)$ monocytes or $(B)$ macrophages adhered to buffer-coated, BSA-coated, or Clq-coated surfaces. Open and stippled bars are as defined in the legend to Fig. 5. With monocytes, only when TCT were added to cells adhered to a Clq-coated surface was the mean value significantly different from the mean value of the control at the $P<0.01$ level. No significant differences were found in the case of Epi. When TCT were used to infect macrophages plated on Clq, the mean values differ significantly from the mean value of the control at the $P<0.005$. Internalization of Epi by macrophages plated on Clq was not enhanced in comparison to macrophages adhered to BSA, but was augmented in comparison to buffer $(P<0.02)$.

face receptor, or the interaction of ligand with its cell receptor can influence an unrelated opsonic receptor to enhance internalization. This latter mechanism appears to operate for the Clq-mediated enhancement of phagocytosis of erythrocytes bearing IgG (28). For $T$. cruzi, it is likely that Clq serves a similar function with phagocytic cells, since enhanced internalization of TCT by monocytes or macrophages was observed when either the parasites were opsonized with Clq (Fig. 5) or the human phagocytes were plated on Clq (Fig. 6). With fibroblasts, Clq functions only as a ligand for attachment (Fig. 7), since plating cells on Clq does not augment TCT internalization (Table I).

Interaction of C1q with fibronectin (32-37) may also enhance parasite entry. Treponema pallidum presensitized with Clq showed increased adherence to fibronectin coated surfaces, although phagocytosis by neutrophils was not enhanced (38). Sorvillo and Pearlstein (39) reported similar findings with $E$. coli and $S$. aureus. TCT and Epi bind fibronectin (40-43); therefore, the interaction of $\mathrm{Clq}$ with fibronectin on the parasite surface may be responsible for some of the effects of $\mathrm{Clq}$ reported here. Inclusion of RGDS during incubation of Clq and the parasites did not block the Clq-mediated augmentation of attachment and internalization, whereas the peptide did block enhancement of these functions seen with fibronectin. The possibility that Clq on the parasite binds to fibronectin on the macrophage (monocytes do not synthesize or express fibronectin) or fibroblast surface has not been excluded, although inclusion of RGDS during incubation of Clq-coated parasites with fibroblasts did not decrease the Clq-mediated enhancement of attachment and entry (Joiner, K. A., unpub- 

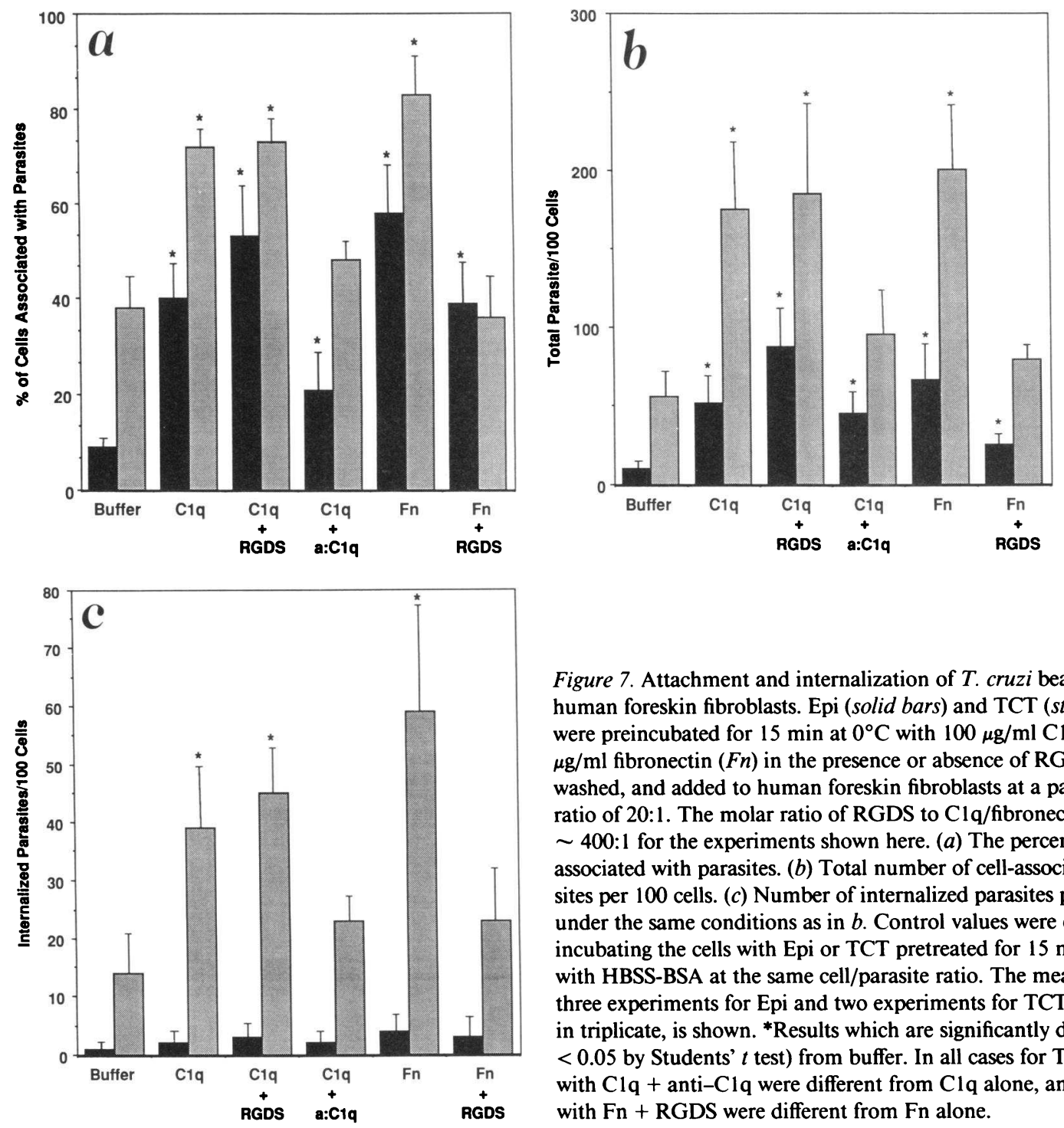

Figure 7. Attachment and internalization of $T$. cruzi bearing Clq by human foreskin fibroblasts. Epi (solid bars) and TCT (stippled bars) were preincubated for $15 \mathrm{~min}$ at $0^{\circ} \mathrm{C}$ with $100 \mu \mathrm{g} / \mathrm{ml} \mathrm{Clq}$ or 100 $\mu \mathrm{g} / \mathrm{ml}$ fibronectin $(F n)$ in the presence or absence of RGDS, then washed, and added to human foreskin fibroblasts at a parasite/cell ratio of 20:1. The molar ratio of RGDS to $\mathrm{Clq} / \mathrm{fibronectin}$ was $\sim 400: 1$ for the experiments shown here. (a) The percentage of cells associated with parasites. $(b)$ Total number of cell-associated parasites per 100 cells. (c) Number of internalized parasites per 100 cells under the same conditions as in $b$. Control values were obtained by incubating the cells with Epi or TCT pretreated for $15 \mathrm{~min}$ at $0^{\circ} \mathrm{C}$ with HBSS-BSA at the same cell/parasite ratio. The mean \pm SD from three experiments for Epi and two experiments for TCT, each done in triplicate, is shown. ${ }^{*}$ Results which are significantly different $(P$ $<0.05$ by Students' $t$ test) from buffer. In all cases for TCT, results with $\mathrm{Clq}+$ anti-Clq were different from $\mathrm{Clq}$ alone, and results with Fn + RGDS were different from Fn alone.

lished observations). Whether or not fibronectin or other extracellular matrix proteins are involved, our results differ from those previously reported $(28,32,38,39)$, since purified $\mathrm{Clq}$ alone potentiates internalization of TCT without an additional requirement for $\mathrm{C} 3$ fragments or $\mathrm{IgG}$ on the target particle.

Table I. Attachment and Internalization of T. cruzi by Human Foreskin Fibroblasts Plated on Clq

\begin{tabular}{|c|c|c|c|c|c|c|}
\hline \multirow[b]{2}{*}{ Ligand on plate } & \multicolumn{2}{|c|}{$\begin{array}{l}\text { Cells associated } \\
\text { with parasites }\end{array}$} & \multicolumn{2}{|c|}{$\begin{array}{l}\text { Total parasites } \\
\text { per } 100 \text { cells }\end{array}$} & \multicolumn{2}{|c|}{$\begin{array}{l}\text { Internalized } \\
\text { parasites } \\
\text { per } 100 \text { cells }\end{array}$} \\
\hline & Epi & TCT & Epi & TCT & Epi & TCT \\
\hline & \multicolumn{2}{|c|}{$\%$} & \multicolumn{2}{|r|}{$n$} & \multicolumn{2}{|r|}{$n$} \\
\hline BSA & $44 \pm 11^{*}$ & $43 \pm 14$ & $54 \pm 10$ & $276 \pm 96$ & $2 \pm 2$ & $26 \pm 13$ \\
\hline $\mathrm{Clq}$ & $38 \pm 17$ & $62 \pm 21$ & $62 \pm 29$ & $361 \pm 134$ & $3 \pm 2$ & $42 \pm 10$ \\
\hline \multicolumn{7}{|l|}{$\mathrm{Clq}$} \\
\hline+ anti-Clq & $50 \pm 14$ & $54 \pm 17$ & $64 \pm 27$ & $294 \pm 40$ & $5 \pm 4$ & $37 \pm 17$ \\
\hline
\end{tabular}

* Mean \pm SD from two experiments, each performed in triplicate.
The collagen-like tail domain of Clq mediates the enhancement of phagocytosis of particles by monocytes and macrophages (28). In normal human serum, however, $\mathrm{Cl}$ exists as a loosely associated macromolecular complex composed of $\mathrm{Clq}, \mathrm{Clr}_{2}, \mathrm{Cls}_{2}$ (reviewed in Cooper [44]) in which the cell-binding region of the collagen-like tail region of $\mathrm{Clq}$ is not exposed. Activation of $\mathrm{Cl}$, which is initiated by interaction of the globular head regions of $\mathrm{Clq}$ with the activating surface, renders the $\mathrm{Cl}_{2} \mathrm{~S}_{2}$ enzyme susceptible to inactivation by the serum regulatory glycoprotein, $\mathrm{Cl}$ inhibitor. In this process, $\mathrm{Cl}$ inhibitor dissociates $\mathrm{Cl}_{2}, \mathrm{Cls}_{2}$ from the Clq-activator complex, thereby exposing the collagen-like tail domain of $\mathrm{Clq}$ to the microenvironment (44-47). Although conventional activation was not observed in this in vitro system, proteolytic degradation of native $\mathrm{Cl}$ by TCT and Epi (Fig. 4) could result in exposure of $\mathrm{Clq}$ tails to receptors on phagocytic cells. Although degradation of Clq by both Epi and TCT occurs, $>60 \%$ of Clq remains intact on the infectious TCT stage, whereas $<10 \%$ of the Clq remains intact on Epi. Furthermore, it is possible that free cleavage fragments enhance internalization, since the purified collagenous-like tail region of Clq enhances ingestion of opsonized targets by monocytes 
and macrophages (27). Finally, it remains to be determined if both $\mathrm{Cls}$ and $\mathrm{Clq}$ degradation occur in normal serum or plasma.

Serum components other than $\mathrm{Clq}$ and fibronectin enhance trypomastigote invasion of cultured cells. Protease (48), phospholipase D (49), the serum lipoprotein cruzin (21), and specific antibodies (50), the first three of which are present in normal serum, also enhance infection. In at least one report, inclusion of fetal calf serum in the assay decreased attachment and invasion of $\mathrm{LLCMK}_{2}$ cells by TCT (31), whereas other workers report an increase in internalization with both calf and human serum (51). Given the complex interplay among Clq, extracellular matrix proteins, and TCT, it is unlikely that only one serum component will mediate the enhanced trypomastigote invasion after serum incubation. Nonetheless, our results indicate that a substantial portion of the enhanced invasion following serum treatment is due to $\mathrm{Clq}$.

These results with $T$. cruzi contrast dramatically with those for infection of cells by related Leishmania spp. Attachment and infectivity of metacyclic promastigotes of $L$. major is enhanced by serum treatment $(2,52)$. In this instance, however, enhancement is due to high-level deposition of $\mathrm{C} 3$ on the promastigote surface during serum incubation (53) and the subsequent interaction of bound C3 fragments with CR1 (52) or CR3 on macrophages. The fundamental difference in the mechanism of serum resistance between infective forms of $T$. cruzi and $L$. major may thus dictate, at least in part, the ligand receptor interactions and the host-cell range which lead to cell invasion. Leishmania spp., which resist serum killing at the terminal portion of the complement cascade, bear large numbers of $\mathrm{C} 3$ fragments after serum incubation (53) and are thus suited to enter their obligatory host cell, the macrophage, via receptors for C3. Trypomastigotes of $T$. cruzi, which produce a C3 convertase inhibitor that prevents deposition of C3 (15-18) but not of Clq during serum treatment, are directed to cells bearing $\mathrm{Clq}$ receptors and fibronectin, of which connective tissue cells such as fibroblasts are the prototype (54).

\section{References}

1. Blackwell, J. M., R. A. B. Ezekowitz, M. B. Roberts, J. Y. Channon, R. B. Sim, and S. Gordon. 1985. Macrophage complement and lectin-like receptors bind Leishmania in the absence of serum. $J$. Exp. Med. 162:324-331.

2. Mosser, D. M., and P. J. Edelson. 1987. The third component of complement (C3) is responsible for the intracellular survival of Leishmania major. Nature (Lond.). 327:329-331.

3. Mosser, D. M., and P. J. Edelson. 1985. The mouse macrophage receptor for C3bi (CR3) is a major mechanism in the phagocytosis of Leishmania promastigotes. J. Immunol. 135:2785-2789.

4. Payne, M. R., and M. A. Horwitz. 1987. Phagocytosis of Legionella pneumophila is mediated by human monocyte complement receptors. J. Exp. Med. 166:1377-1389.

5. Bellinger-Kawahara, C. G., and M. A. Horwitz. 1987. The major outer membrane protein is a prominent acceptor molecule for complement component $\mathrm{C} 3$ on Legionella pneumophila. Clin. Res. 35:617A. (Abstr.)

6. Bullock, W. E., and S. D. Wright. 1987. Role of the adherencepromoting receptors, CR3, LFA-1, and p150, 95, in binding of Histoplasma capsulatum by human macrophages. J. Exp. Med. 165:195210.

7. Wozencraft, A. O., G. Sayers, and J. M. Blackwell. 1986. Macro- phage type 3 complement receptors mediate serum-independent binding of Leishmania donovani. J. Exp. Med. 164:1332-1337.

8. Ezekowitz, R. A. B., R. B. Sim, M. Hill, and S. Gordon. 1984. Local opsonization by secreted macrophage complement components: role of receptors for complement in uptake of zymosan. J. Exp. Med. 159:244-260.

9. Russell, D. G., and S. D. Wright. 1988. Complement receptor type 3 (CR3) binds to an Arg-Gly-Asp-containing region of the major surface glycoprotein, gp63, of Leishmania promastigotes. J. Exp. Med. 168(1):279-292.

10. Zingales, B., and W. Colli. 1985. Curr. Top. Microbiol. Immunol. 117:129-152.

11. Nogueira, N., and Z. A. Cohn. 1976. Trypanosoma cruzi: mechanism of entry and intracellular fate in mammalian cells. J. Exp. Med. 143:1402-1420.

12. Hieny, S., R. P. da Silva, and A. Sher. 1988. Complement enhances the survival of metacyclic trypomastigotes of Trypanosoma cruzi in mouse peritoneal macrophages. FASEB (Fed. Am. Soc. Exp. Biol.) J. 2:A678. (Abstr.)

13. Joiner, K., S. Hieny, L. V. Kirchhoff, and A. Sher. 1985. gp72, the 72-kilodalton glycoprotein, is the membrane acceptor site for $\mathrm{C} 3$ on Trypanosoma cruzi. J. Exp. Med. 161:1196-1212.

14. Schenkman, S., M. L. Guther, and N. Yoshida. 1986. Mechanism of resistance to lysis by the alternative complement pathway in Trypanosoma cruzi trypomastigotes: effect of a specific monoclonal antibody. J. Immunol. 137:1623-1628.

15. Sher, A., S. Hieny, and K. Joiner. 1986. Evasion of the alternative complement pathway by metacyclic trypomastigotes of Trypanosoma cruzi: dependence on the developmentally regulated synthesis of surface protein and N-linked carbohydrate. J. Immunol. 137:29612967.

16. Joiner, K., A. Sher, T. Gaither, and C. Hammer. 1986. Evasion of alternative complement pathway by Trypanosoma cruzi results from inefficient binding of factor B. Proc. Natl. Acad. Sci. USA. 83:6593-6597.

17. Rimoldi, M. T., A. Sher, S. Hieny, A. Lituchy, C. H. Hammer, and K. Joiner. 1988. Developmentally regulated expression by Trypanosoma cruzi of molecules which accelerate the decay of complement C3 convertases. Proc. Natl. Acad. Sci. USA. 85:193-197.

18. Joiner, K. A., W. D. da Silva, M. T. Rimoldi, C. H. Hammer, A. Sher, and T. L. Kipnis. 1988. Biochemical characterization of a factor produced by trypomastigotes of Trypanosoma cruzi which accelerates the decay of complement C3 convertases. J. Biol. Chem. 263:11327-11335.

19. Tenner, A. J., P. H. Lesavre, and N. R. Cooper. 1981. Purification and radiolabelling of human Clq. J. Immunol. 127:648-653.

20. Kolb, W. P., L. M. Kolb, and E. R. Podack. 1979. C1q: isolation from human serum in high-yield by column affinity chromatography and development of a highly sensitive hemolytic assay. J. Immunol. 122:2103-2111.

21. Prioli, R. P., J. M. Ordoses, I. Rosenberg, E. J. Schaefer, and M. E. A. Pereira. 1987. Similarity of cruzin, an inhibitor of Trypanosoma cruzi neuraminidase, to high-density lipoprotein. Science (Wash. DC). 238:1417-1419.

22. Ziccardi, R. J., and N. R. Cooper. 1976. Physicochemical and functional characterization of the $\mathrm{Cl} \mathrm{r}$ subunit of the first complement component. J. Immunol. 116:496-503.

23. Valet, F., and N. R. Cooper. 1974. Isolation and characterization of the proenzyme form of the $\mathrm{C} 1 \mathrm{~s}$ subunit of the first complement component. J. Immunol. 112:339-347.

24. Prograis, L. D. Jr., C. H. Hammer, K. Katusha, and M. M. Frank. 1987. Purification of $\mathrm{Cl}$ inhibitor: a new approach for the isolation of this biologically important plasma protease inhibitor. $J$. Immunol. Methods 99:113-122.

25. Chesne, S., C. L. Villiers, G. J. Arlaud, M. B. Lacroix, and M. G. Colomb. 1982. Fluid phase interaction of $\mathrm{Cl}$ inhibitor (C1 Inh) and the subcomponents $\mathrm{Clr}$ and $\mathrm{Cls}$ of the first component of complement C1. Biochem. J. 201:61-70. 
26. Cooper, N. R., and R. J. Ziccardi. 1977. Reconstitution of C1 in native, proenzyme form and its use in a quantitative $\mathrm{Cl}$ activation test. J. Immunol. 119:1664-1667.

27. Lionetti, F. J., S. M. Hunt, and C. R. Valeri. 1980. In Methods of Cell Separation. N. Catsimpoolas, editor. Plenum Publishing Corp., New York. 141.

28. Bobak, D. A., T. A. Gaither, M. M. Frank, and A. J. Tenner. 1987. Modulation of FCR function by complement: subcomponent Clq enhances the phagocytosis of IgG-opsonized targets by human monocytes and culture-derived macrophages. J. Immunol. 138:11501156.

29. Bobak, D. A., M. M. Frank, and A. J. Tenner. 1988. Clq acts synergistically with phorbal dibutyrate to activate CR-1-mediated phagocytosis by human mononuclear phagocytes. Eur. J. Immun. 18:2001-2007.

30. Nogueira, N., and Z. Cohn. 1976. Trypanosoma cruzi: mechanism of entry and intracellular fate in mammalian cells. J. Exp. Med. 143:1402-1420.

31. Andrews, N. W., and W. Colli. 1982. Adhesion and interiorization of Trypanosoma cruzi in mammalian cells. J. Protozool. 29:264-269.

32. Sorvillo, J. M., I. Gigli, and E. Pearlstein. 1986. The effect of fibronectin on the processing of $\mathrm{Clq}$ - and $\mathrm{C} 3 \mathrm{~b} / \mathrm{bi}$-coated immune complexes by peripheral blood monocytes. J. Immunol. 136:10231026.

33. Bing, D. H., S. Almeda, H. Isliker, J. Lahav, and R. O. Hynes. 1982. Fibronectin binds to the Clq component of complement. Proc. Natl. Acad. Sci. USA. 79:4198-4201.

34. Menzel, E. J., J. S. Smolen, L. Liotta, and K. B. M. Reid. 1981. Interaction of fibronectin with $\mathrm{Clq}$ and its collagen-like fragment (CLF). FEBS (Fed. Eur. Biochem. Soc.) Lett. 129:188-192.

35. Pearlstein, E., J. Sorvillo, and I. Gigli. 1982. The interaction of human plasma fibronectin with a subunit of the first component of complement, Clq. J. Immunol. 128:2036-2039.

36. Sorvillo, J., I. Gigli, and E. Pearlstein. 1983. Requirements for the binding of human plasma fibronectin to the $\mathrm{Clq}$ subunit of the first component of complement. J. Immunol. 1313:1400-1404.

37. Sorvillo, J., I. Gigli, and E. Pearlstein. 1985. Fibronectin binding to complement subcomponent $\mathrm{Clq}$ : localization of their respective binding sites. Biochem. J. 226:207-215.

38. Baughn, R. E. 1986. Antibody-independent interactions of fibronectin, Clq, and human neutrophils with Treponema pallidum. Infect. Immun. 54:456-464.

39. Sorvillo, J., and E. Pearlstein. 1985. Clq, a subunit of the first component of complement, enhances binding of plasma fibronectin to bacteria. Infect. Immun. 49:664-669.
40. Ouaissi, M. A., J. Cornette, and A. Capron. 1986. Identification and isolation of Trypanosoma cruzi trypomastigote cell surface protein with properties expected of a fibronectin receptor. Mol. Biochem. Parasitol. 19:201-211.

41. Ouaissi, M. A., D. Afchain, A. Capron, and J. A. Grimaud. 1984. Fibronectin receptors on Trypanosoma cruzi trypomastigotes and their biological function. Nature (Lond.). 308:380-382.

42. Wirth, J. J., and F. Kierszenbaum. 1984. Fibronectin enhances macrophage association with invasive forms of Trypanosoma cruzi. $J$. Immunol. 133:460-464.

43. Peyrol, S., M. A. Ouaissi, A. Capron, and J. A. Grimaud. 1987. Trypanosoma cruzi: ultrastructural visualization of fibronectin bound to culture forms. Exp. Parasitol. 63:112-114.

44. Cooper, N. R. 1985. The classical complement pathway: activation and regulation of C1. Adv. Immunol. 37:151-216.

45. Reid, K. B. 1983. Proteins involved in the activation and control of the two pathways of human complement. Biochem. Soc. Trans. 11:1-12.

46. Laurell, A. B., U. Johnson, U. Martensson, and A. G. Sjöholm. 1978. Formation of complex composed of $\mathrm{Cl} r, \mathrm{Cls}$ and $\mathrm{Cl}$ inactivator in human serum activation of C1. Acta Pathol. Microbiol. Scand. Sect. C Immunol. 86:299-306.

47. Ziccardi, R. J., and N. R. Cooper. 1979. Active disassembly of the first complement component $\mathrm{Cl}$, by $\mathrm{Cl}$-inactivator. J. Immunol. 123:788-792.

48. Noguiera, N., S. Chaplan, and Z. Cohn. 1980. Trypanosoma cruzi: factors modifying ingestion and fate of blood form trypomastigotes. J. Exp. Med. 152:447-451.

49. Connelly, M. C., and F. Kierszenbaum. 1985. Increased host cell Trypanosoma cruzi interaction following phospholipase D treatment of the parasite surface. Mol. Biochem. Parasitol. 17:191-202.

50. Cavallesco, R., and M. E. A. Pereira. 1988. Antibody to Trypanosoma cruzi neuraminidase enhances infection in vitro and identifies a subpopulation of trypomastigotes. J. Immunol. 140:617-625.

51. Piras, M. M., R. Piras, and D. Henriquez, with the technical assistance of S. Negri. 1982. Changes in morphology and infectivity of cell culture-derived trypomastigotes of Trypanosoma cruzi. Mol. Biochem. Parasitol. 6:67-81.

52. da Silva, R. P., B. F. Hall, K. A. Joiner, and D. L. Sacks. 1989. $C R 1$, the C3b receptor, mediates binding of infective $L$. major promastigotes to human macrophages. J. Immunol. 143:617-624.

53. Puentes, S. M., D. Sacks, R. da Silva, and K. A. Joiner. 1988. Binding of complement by two developmental stages of Leishmania major varying in expression of a cell surface glycolipid. J. Exp. Med. 137:887-902.

54. Ruoslahti, E. 1988. Fibronectin and its receptors. Ann. Rev. Biochem. 57:375-413. 